\title{
Organization of the double-stranded RNA-activated protein kinase DAI and virus-associated VA RNA in adenovirus-2-infected HeLa cells
}

\author{
Luis F. Jiménez-García*, Simon R. Green, Michael B. Mathews and David L. Spector ${ }^{\dagger}$ \\ Cold Spring Harbor Laboratory, Cold Spring Harbor, New York 11724, USA \\ *Present address: National Autonomous University of Mexico, Departamento de Biology, Mexico, DN Mexico \\ †Author for correspondence
}

\section{SUMMARY}

We have examined the cellular distribution of the double-stranded RNA-activated protein kinase DAI in adenovirus 2 (Ad2) -infected and uninfected HeLa cells. In uninfected cells DAI was found to be concentrated in the cytoplasm. In addition, DAI was localized in the nucleoli and diffusely distributed throughout the nucleoplasm. Cells treated with $\alpha$-interferon displayed a similar pattern of distribution for DAI. When RNA polymerase I activity was inhibited by the drug actinomycin D, nucleoli segregated and DAI was found to colocalize with the dense fibrillar region of the nucleoli. During mitosis, the distribution of DAI paralleled that of rRNA. In adenovirus-infected cells the localization of DAI was similar to that in uninfected interphase cells. VA RNAI was detected in Ad2-infected cells by 10-14 hours postinfection as fine dots in the nucleoplasm. By 18-24 hours post-infection, VA RNAI appeared in bigger and more abundant dots in the nucleoplasm and the cytoplasm was intensively labeled. Transient expression of the VA RNAI gene in uninfected cells resulted in a similar localization of the RNA. Our results are consistent with a role for DAI and VA RNAI in protein synthesis and suggest that DAI may play an early role in ribosome biogenesis in the nucleolus in addition to its cytoplasmic role in translation.

Key words: adenovirus, nucleolus, translation, RNA localization

\section{INTRODUCTION}

Adenovirus 2 (Ad2) belongs to subgroup $\mathrm{C}$ of adenoviruses, which have the ability to transform cells. The virion is 80 $\mathrm{nm}$ in diameter and is composed of a core that includes the viral DNA genome of about $36 \mathrm{~kb}$ and four proteins, and a shell that comprises at least 15 different structural proteins organized in a complex capsid (Pettersson, 1984; Akusjärvi et al., 1986; Stewart et al., 1991). Whereas the majority of the viral genome is transcribed by RNA polymerase II (see Ziff, 1980; Tooze, 1982; Flint, 1986; Akusjärvi et al., 1986), the two virus-associated (VA) RNAs, VA RNAI and VA RNA II (Reich et al., 1966) are synthesized by RNA polymerase III (Price and Penman, 1972; Mathews, 1975; Akusjärvi et al., 1980; Akusjärvi et al., 1986). These two small, noncoding RNAs are about 160 nucleotides long (Akusjärvi et al., 1980) and are transcribed from the r-strand at about 30 map units in the genome (Mathews, 1975; Akusjärvi et al., 1980; Akusjärvi et al., 1986). Although the genes for these RNAs are arranged in tandem and separated by a short DNA spacer (Mathews, 1975; Mathews and Pettersson, 1978; Akusjärvi et al., 1980) they are differentially expressed. Both RNAs are produced early in infection but VA RNAI synthesis increases rapidly in the late phase and becomes the most abundant RNA in the cytoplasm of infected cells (Söderlund et al., 1976).
Although regulation of $\mathrm{Ad} 2$ mRNA formation late in infection takes place extensively in the cell nucleus, including control of transcription and post-transcriptional events such as methylation, splicing, polyadenylation and transport (see McGrogan and Raskas, 1977; Nevins and Darnell, 1978; Philipson 1979; Ziff, 1980; Tooze, 1982; Darnell, 1982; Sharp, 1984; Flint, 1986), once in the cytoplasm, a complex series of events regulate the expression of the $\mathrm{Ad} 2$ genome at the level of protein synthesis.

During the late phase of infection, cellular protein synthesis is inhibited while viral protein production is enhanced (Beltz and Flint, 1979). The mechanism whereby the cellular translational apparatus is selectively engaged in viral protein synthesis is not fully understood despite considerable effort expended to try to understand the different aspects of this phenomenon (Mathews, 1990; Zhang and Schneider, 1993). Translational control in adenovirus infected cells involves the participation of the cellular kinase DAI (double-stranded RNA-activated inhibitor of translation) and the small viral VA RNAI (see Mathews, 1990; Mathews et al., 1990; Mathews and Shenk, 1991).

DAI, also known as the interferon-induced protein kinase (p68) is present in a latent form in most cells (Kostura and Mathews, 1989; Mathews and Shenk, 1991). It is activated by low concentrations of double-stranded (ds) RNA, probably generated during viral infection by symmetrical tran- 
scription of the genome (Maran and Mathews, 1988), but high concentrations of dsRNA prevent such an activation (Mathews et al., 1990; Mathews and Shenk, 1991). Upon binding of dsRNA, the protein displays two kinase activities. First, the enzyme autophosphorylates, resulting in unmasking of its second activity, which is to phosphorylate the $\alpha$ subunit of the eukaryotic translation initiation factor-2 (eIF2). In uninfected cells, DAI remains in a latent, inactive form and does not phosphorylate eIF-2, allowing this factor to engage in multiple rounds of initiation of protein synthesis (Schneider et al., 1984, 1985; Reichel et al., 1985; Mathews, 1990; Mathews et al., 1990; Mathews and Shenk, 1991).

A mutant virus lacking the gene for VA RNA grows poorly, and the defect was ascribed to a lesion in protein synthesis (Thimmappaya et al., 1982; Mathews, 1990; Mathews and Shenk, 1991). The sequence of VA RNA Is known (Akusjärvi et al., 1980; Pe'ery et al., 1993). It forms extensive secondary structure (Furtado et al., 1989; Mellits and Mathews, 1988; Pe'ery et al., 1993) and functions to prevent DAI activation. In fact, VA RNAI can bind to DAI (Katze et al., 1987; Galabru et al., 1989; Mellits et al., 1990a) mediated principally by its duplexed apical stem (Mellits et al., 1990a; Ghadge et al., 1991; Clarke et al., unpublished), while another structural feature, the central domain, is responsible for the blocking function (Mellits and Mathews, 1988; Furtado et al., 1989; Mellits et al., 1990b).

During adenovirus infection, VA RNA I prevents the activation of DAI by viral dsRNA (Maran and Mathews, 1988), thereby maintaining the rate of protein synthesis in the cell (Mathews, 1990; Mathews et al., 1990; Mathews and Shenk, 1991). In addition, it has been proposed that the VA RNA $A_{-}$DAI system contributes to the preferential translation of viral mRNAs late in infection (O'Malley et al., 1989; Svensson and Akusjärvi, 1985).

In the present study we have used polyclonal and monoclonal antibodies to DAI and a DNA probe to Ad2 VA RNAI to localize these molecules in the cell by immunofluorescence microscopy and in situ hybridization. Single- and double-label (data not shown) experiments have shown that DAI and VA RNAI localize diffusely in the cytoplasm of infected cells late in infection. Furthermore, DAI was found in the nucleolus and nucleoplasm of uninfected and infected cells. VA RNA I was localized as discrete and abundant small round bodies in the nuclei of infected cells or uninfected cells transfected with the VA RNAI gene. Our results provide cytochemical evidence to support the role of DAI and VA RNA In $_{\text {in }}$ protein synthesis late in adenovirus infected cells, and also suggest a possible role for DAI in the early steps of ribosome biogenesis within the nucleolus.

\section{MATERIALS AND METHODS}

\section{Cells, virus and infection}

HeLa cells were grown on glass coverslips for 1-2 days in Dulbecco's modified Eagle's medium (Gibco) containing 10\% fetal bovine serum. Cells were infected with wild type adenovirus-2 (Ad2) at a multiplicity of infection (moi) of 30 plaque forming units (pfu)/cell. After 1 hour of adsorption, the monolayers were rinsed with PBS and fresh medium was added. Further incubation for $7,10,14,18$ or 24 hours was carried out before in situ hybridization or immunocytochemistry.

\section{Antibodies and probes}

Polyclonal antibodies were prepared as described (Green and Mathews, 1992). Monoclonal antibody to DAI (Laurent et al., 1985) was a gift from A. G. Hovanessian (Institut Pasteur). Human autoantibody to fibrillarin was provided by R. L. Ochs (Scripps Research Institute). Approximately $3 \mu \mathrm{g}$ of DNA encoding VA RNA $_{\text {I }}$ (plasmid pT7VA/Ad2I; Mellits et al., 1990b) was labeled by nick translation in the presence of $50 \mu \mathrm{M}$ of bio-11-dUTP (Sigma), dATP, dCTP and dGTP. The size of the resulting fragments was monitored by electrophoresis in a $1 \%$ agarose gel. Nick translation reactions were stopped when a fragment size of about 200 base pairs was obtained. The probe was purified through a Sephadex G-50 (Boehringer Mannheim) column and stored at $-20^{\circ} \mathrm{C}$ until use.

\section{Immunofluorescence}

After fixation for 15 minutes with $2 \%$ paraformaldehyde or for 3 minutes at $-20^{\circ} \mathrm{C}$ with $100 \%$ methanol, immunofluorescence was performed as described (Spector and Smith, 1986) using polyclonal antibodies to DAI at a dilution of 1:30 or monoclonal antibodies to DAI at a dilution of 1:5 in Tris buffered saline (TBS:

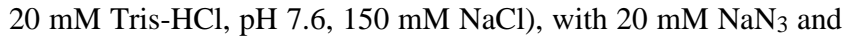
$1 \%$ Tween-20. As controls, we performed immunofluorescence with preimmune serum for the polyclonal antibody or with antibodies to DAI preabsorbed with immunoaffinity purified (Galabru and Hovanessian, 1987) or glycerol gradient fractionated (Kostura and Mathews, 1989) DAI. Incubation times with the first antibody were either 1 hour at room temperature or 16 hours at $4^{\circ} \mathrm{C}$. Texas Red-conjugated horse anti-mouse, Texas Red-conjugated goat anti-rabbit (Vector, Burlingame California) or FITC-conjugated goat anti-mouse (Organon-Teknika, West Chester, PA) secondary antibodies were used at a dilution of 1:20 in TBS plus 5\% bovine serum albumin (BSA) and 5\% normal goat serum (NGS). Coverslips were mounted in anti-fade medium (90\% glycerol, $10 \%$ PBS plus $1 \mathrm{mg} / \mathrm{ml}$ of paraphenylenediamine). The final $\mathrm{pH}$ was adjusted to 8.0 with $0.5 \mathrm{M}$ carbonate-bicarbonate buffer, $\mathrm{pH} 9.0$. Cells were examined with a Nikon (Nikon Inc., Melville, New York) FXA epifluorescence microscope equipped with a $\times 60,1.4$ NA objective lens.

\section{In situ hybridization and detection}

Cells were fixed with freshly made $2 \%$ or $4 \%$ paraformaldehyde in PBS, $\mathrm{pH} 7.3$, for 15 minutes at room temperature at $0,7,10$, 14, 18 and 24 hours post-infection (hpi). After rinsing in PBS ( $3 \times$ 10 minutes each), cells were permeabilized with $0.2 \%$ Triton $\mathrm{X}$ $100 / 0.5 \%$ NGS for 5 minutes at $4^{\circ} \mathrm{C}$, then rinsed in PBS $(3 \times 10$ minutes each) and in $2 \times$ SSC (5 minutes). For each coverslip, 750 ng of nick translated DNA encoding VA RNAI and $20 \mu \mathrm{g}$ of carrier E. coli tRNA were dried down in a Speed Vac (Savant). The probe and tRNA were denatured by heating in $10 \mu \mathrm{l}$ of deionized formamide for 10 minutes at $70^{\circ} \mathrm{C}$. The probe was chilled on ice immediately and hybridization buffer containing $4 \mu \mathrm{l}$ of $5 \%$ BSA, $4 \mu \mathrm{l}$ of $50 \%$ dextran sulfate, and $2 \mu \mathrm{l}$ of $20 \times$ SSC was added to each tube so that the final concentration in the hybridization mixture was about $40 \mathrm{ng} / \mu \mathrm{l}$ of the VA RNAI probe, 1 $\mu \mathrm{g} / \mu \mathrm{l}$ of $E$. coli tRNA, $4 \times \mathrm{SSC}, 1 \%$ BSA and $10 \%$ dextran sulfate. Then, $20 \mu \mathrm{l}$ of hybridization mixture was placed onto each coverslip. Coverslips were inverted onto a slide, sealed with rubber cement, and incubated in a humidified chamber for 16 hours at $42^{\circ} \mathrm{C}$. After rinsing in $2 \times \mathrm{SSC}, 50 \%$ formamide at $37^{\circ} \mathrm{C}$, $2 \times \mathrm{SSC}$ and $1 \times \mathrm{SSC}$ at room temperature for 30 minutes each, cells were incubated in $4 \times \mathrm{SSC}, 0.25 \% \mathrm{BSA}$, and $2 \mu \mathrm{g} / \mu \mathrm{l}$ avidinFITC (Vector, Burlingame, California) for 90 minutes at room temperature in a humidified chamber in the dark. Coverslips were then rinsed in $4 \times \mathrm{SSC}$ for 30 minutes at room temperature, $4 \times$ SSC, $0.1 \%$ Triton $\mathrm{X}-100$ for 10 minutes and $4 \times$ SSC three times 

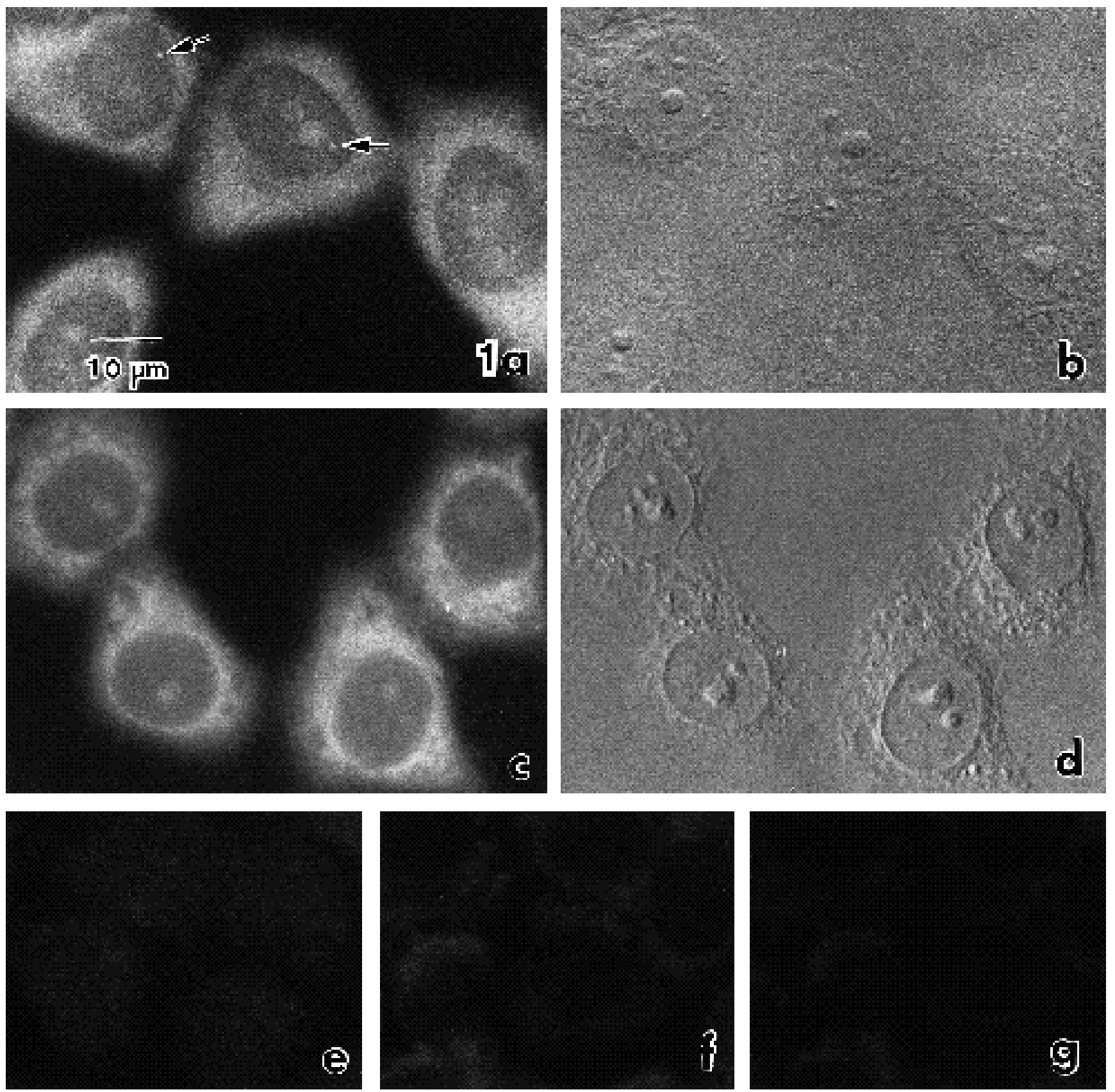

Fig. 1. Localization of DAI in uninfected HeLa cells. Immunofluorescence using polyclonal (a) or monoclonal (c) antibodies, and corresponding differential interference contrast images (b, d) of HeLa cells shows the presence of DAI in the cytoplasm, and nucleoli. The nucleoplasm is also slightly labeled. Coiled bodies were also labeled with polyclonal antibodies to DAI (a, arrows). Cells incubated with preimmune serum (e) or monoclonal antibodies to DAI preabsorbed with immunoaffinity purified (Galabru and Hovanessian, 1987) (f) or glycerol gradient fractionated DAI (Kostura and Mathews, 1989) (g) used as primary antibodies, showed no signal.

for 10 minutes each. Coverslips were mounted in $90 \%$ glycerol, $10 \%$ PBS, containing $1 \mathrm{mg} / \mathrm{ml}$ paraphenylenediamine as an antioxidant to prevent bleaching. Cells were examined with a Nikon FXA epifluorescence microscope.

\section{In situ hybridization-immunofluorescence combined protocols}

Immunofluorescence following in situ hybridization was conducted as described (Huang and Spector, 1991) with the follow- ing modifications. Briefly, cells were hybridized as above and after incubation in FITC-avidin to detect the hybrids, and washes with $4 \times$ SSC, cells were placed in PBS for 10 minutes and incubated with monoclonal antibody to DAI as described above. The inverse procedure, antibody labeling followed by in situ hybridization, was also carried out and produced similar results.

\section{Confocal laser scanning microscopy}

A Zeiss (Carl Zeiss Inc., Thornwood, New York) confocal laser 
scanning microscope, equipped with a $\times 63 / 1.4$ NA oil immersion lens and an argon ion laser (wavelength, $488 \mathrm{~nm}$ ) to excite FITCfluorescence was used for optical sectioning. Data sets of optical sections were collected at $250 \mathrm{~nm}$ intervals through each nucleus. Single optical sections and left/right stereo pairs of labeled nuclei reconstructed from serial optical sections were generated using the Zeiss Confocal Laser Scanning software version 2.03. Images were recorded on a Sony color video printer (Mavigraph) and on Kodak T-Max 100 film or Kodak Ektachrome 100 HC film using a Matrix Multicolor image recording system.

\section{Nuclease digestions}

Paraformaldehyde fixed cells were treated with either DNase I or RNase A at a concentration of $100 \mu \mathrm{g} / \mathrm{ml}$ for 2 hours at room temperature. After extensive washes cells were prepared for in situ hybridization as described above.

\section{Post-embedding immunoelectron microscopy}

Monolayers of HeLa cells were fixed in $4 \%$ paraformaldehyde plus $0.05 \%$ glutaraldehyde in PBS, $\mathrm{pH} 7.3$, dehydrated in ethanol and embedded in Lowicryl K4M resin. Thin sections $(80 \mathrm{~nm})$ were cut with a Reichert-Jung Ultracut E ultramicrotome using a Diatome diamond knife and were mounted on gold grids. The grids were floated in TBS for 60 minutes at room temperature and incubated with monoclonal antibody to DAI at a dilution of $1: 2$ in TBS for $16 \mathrm{~h}$ at $4^{\circ} \mathrm{C}$. Then $15 \mathrm{~nm}$ colloidal gold-conjugated goat anti-mouse IgG (Amersham) (diluted 1:20 in TBS) was used as secondary antibody for 60 minutes at room temperature. After rinsing with TBS for 10 minutes, grids were washed with distilled water and stained with uranyl acetate and lead citrate. The samples were observed with a Hitachi H-7000 transmission electron microscope (Hitachi Ltd., Rockville, MD) operating at $75 \mathrm{kV}$.

\section{Drug studies}

HeLa cells growing on coverslips were exposed to $0.2 \mu \mathrm{g} / \mathrm{ml}$ of actinomycin D for 4 hours at $37^{\circ} \mathrm{C}$ (Ochs et al., 1985a). After drug treatment, cells were immunolabeled as described above with a monoclonal antibody to DAI or human autoantibody against fibrillarin at a dilution of 1:200. Detection was carried out with secondary antibodies coupled to FITC or Texas Red, respectively.

\section{Transfection}

HeLa cells growing on coverslips were transfected with 2.5 $\mu \mathrm{g} /$ coverslip of plasmid pMHVA (Mellits and Mathews, 1988) for 6 hours, using a modified calcium phosphate technique (Wigler et al., 1978). Cells were then fixed and processed for in situ hybridization using the pT7VA/Ad2I probe 24,48 and 60 hours posttransfection. Control cells were transfected with $2.5 \mu \mathrm{g}$ of plasmid pUC119.

\section{Interferon treatment}

HeLa cells growing on coverslips were treated with $\alpha$-interferon (obtained from Paul Trotta, Schering Corp., Bloomfield, New Jersey) at a concentration of 800 units $/ \mathrm{ml}$ for 18 hours at $37^{\circ} \mathrm{C}$. After the treatment, cells were immunolabeled with monoclonal antibody to DAI.

\section{RESULTS}

\section{DAI localizes in the cytoplasm and nucleoli of uninfected and Ad2 infected HeLa cells}

We have localized DAI in the cytoplasm and nucleoli of uninfected HeLa cells with either polyclonal (Fig. 1a) or monoclonal (Fig. 1c) antibodies directed against the pro- tein. Intense and almost homogeneous signal was observed in the cytoplasm. In addition, a weaker fluorescence was detected in the nucleoli and also a diffuse labeling of the nucleoplasm was observed. The labeling with polyclonal and monoclonal antibodies was similar but with the polyclonal antibody we consistently observed the staining of additional nuclear bodies that we identified as coiled bodies (Fig. 1a). The significance of the presence of DAI in the coiled bodies is unclear. Coiled bodies are ribonucleoprotein structures that contain factors related to pre-rRNA and pre-mRNA metabolism (Brasch and Ochs, 1992). However, they are not present in all cells and they appear to be characteristic of transformed cells (Spector et al., 1992).

The specificity of the antibodies used in this study was demonstrated by performing immunofluorescence with a preimmune serum (Fig. 1e) and with anti-DAI antibody, which was preabsorbed with purified DAI protein (Fig. 1fg). In both cases, no signal was observed in the cytoplasm, nucleoplasm or nucleolus. The specificity of the monoclonal antibody was previously demonstrated by immunoblot and immunoprecipitation (Laurent et al., 1985). This antibody
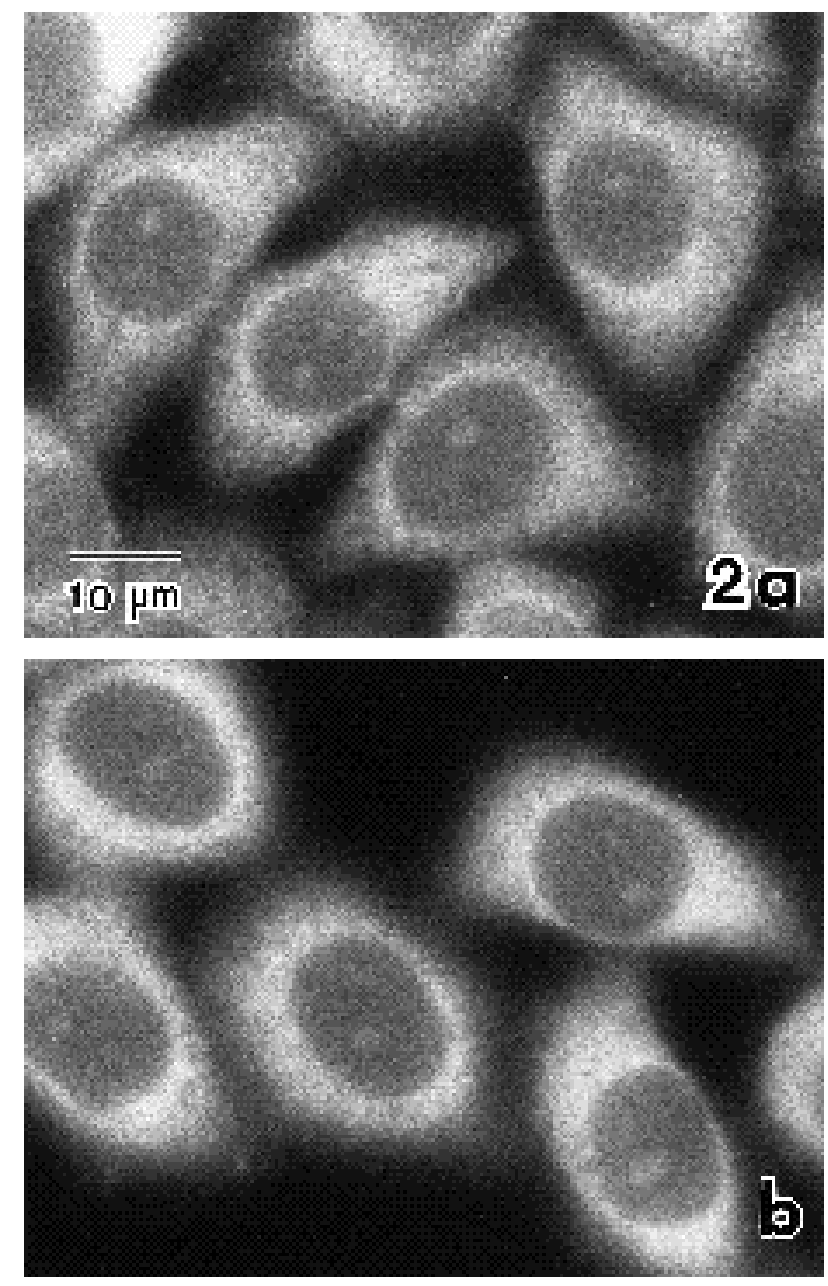

Fig. 2. Immunofluorescent localization of DAI in uninfected $\alpha$ interferon treated HeLa cells. Cells untreated (a) or treated with $\alpha$ interferon (b) both display cytoplasmic and nucleolar localization of DAI. 

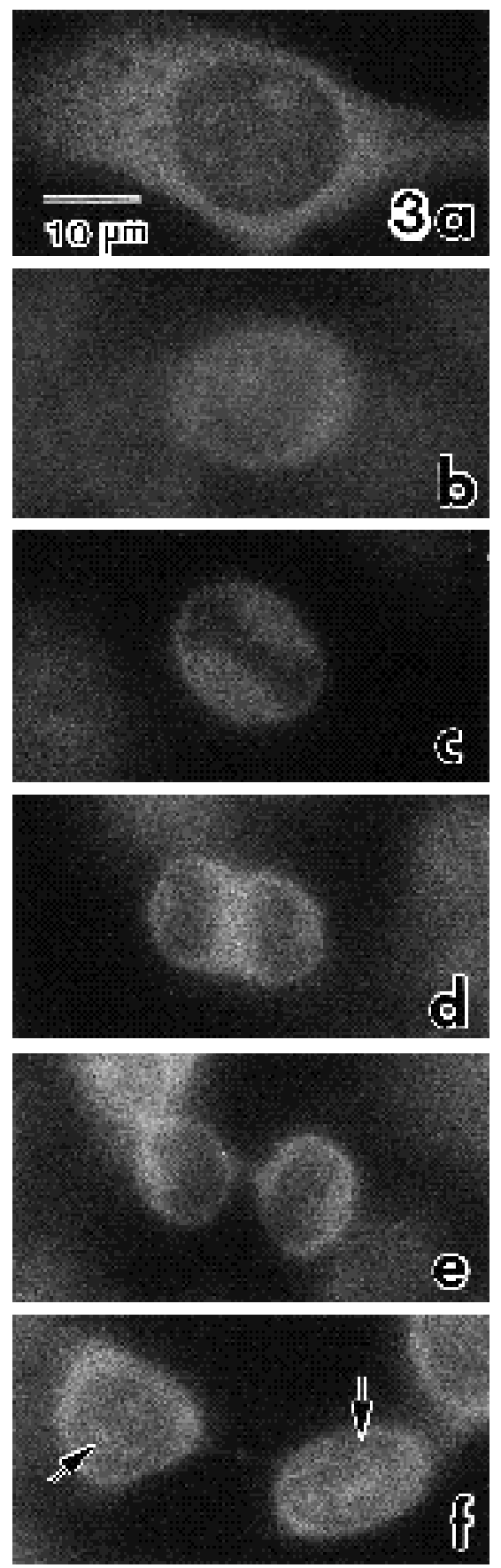

Fig. 3. Immunofluorescent localization of DAI in uninfected HeLa cells during mitosis. Interphase cells (a) showed cytoplasmic staining as well as faint labeling in nucleoli and nucleoplasm. During prophase (b), nucleolar DAI is diffusely distributed as the nucleolus breaks down. In metaphase (c), anaphase (d) and telophase (e) the chromosomes are not labeled. By early $\mathrm{G}_{1}$ (f) DAI appears in the newly forming nucleoli (arrows).

was used for all subsequent immunolocalization experiments. Since DAI is an interferon-induced protein we determined the localization of this kinase after $\alpha$-interferon treatment. Interferons (IFNs) are cytokines with antiviral, cell growth regulatory and immunomodulatory activities (Pestka et al., 1987). Binding of IFNs to the cell surface
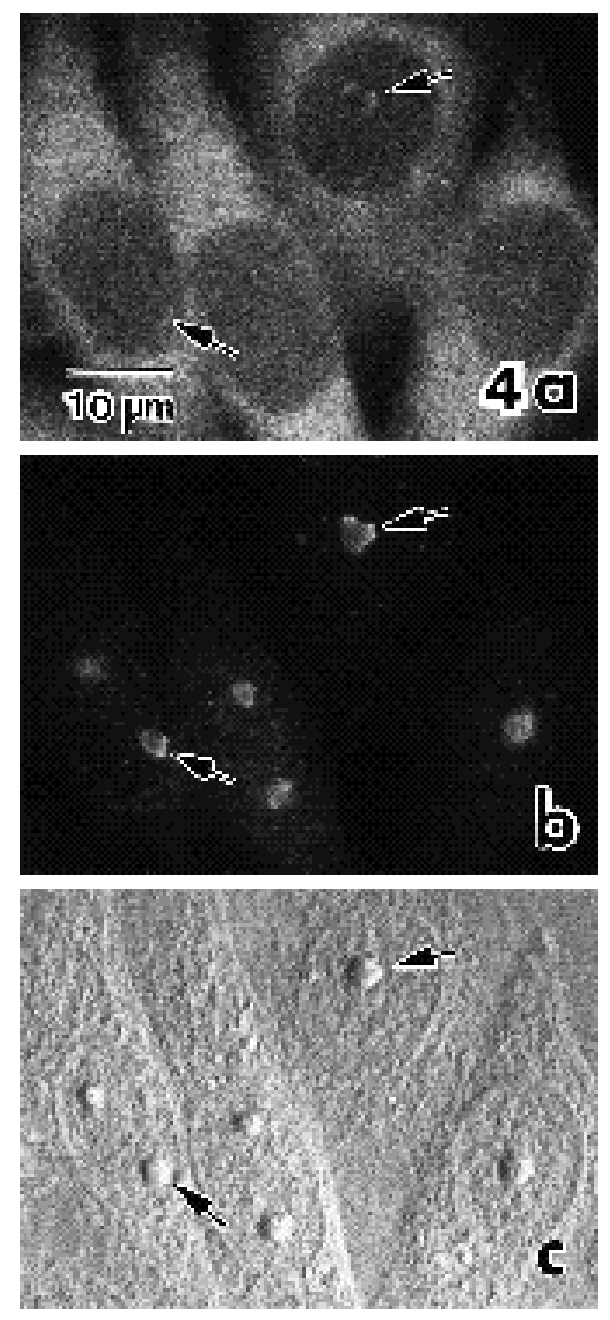

Fig. 4. Distribution of DAI in uninfected actinomycin D-treated HeLa cells. Double-label immunofluorescence of cells with antiDAI (a) and anti-fibrillarin (b) antibodies after treatment with 0.2 $\mu \mathrm{g} / \mathrm{ml}$ of actinomycin D for 4 hours shows cytoplasmic staining for DAI (a). Colocalization of DAI and fibrillarin is observed in the segregated nucleoli (a-c, arrows). (c) Corresponding differential interference contrast image.

induces the synthesis of several proteins, including DAI, that are localized to the cytoplasm and nuclei. Treatment of HeLa cells with 800 units/ml of $\alpha$-interferon did not alter the distribution of DAI, although the signal appeared brighter (Fig. 2b) than in non-treated cells (Fig. 2a). Other proteins such as the Mx family (Pavlovic and Staehli, $1991)$, and some isoenzymes from the $\left(2^{\prime}-5^{\prime}\right)$ oligoadenylate synthetase family have been localized to the nucleus (Chebath et al., 1987). Recently, the murine IFN-induced $72 \mathrm{kDa}$ protein encoded by the Ifi 204 gene was also found in the nucleolus (Choubey and Lengyel, 1992). These observations and our results suggest that nuclear localization may be a common characteristic of IFN-induced proteins.

To correlate the distribution of DAI with other cytoplasmic and nucleolar components we monitored the behavior of DAI during mitosis (Fig. 3). Label remained distributed in the cytoplasm during the different phases of mitosis 

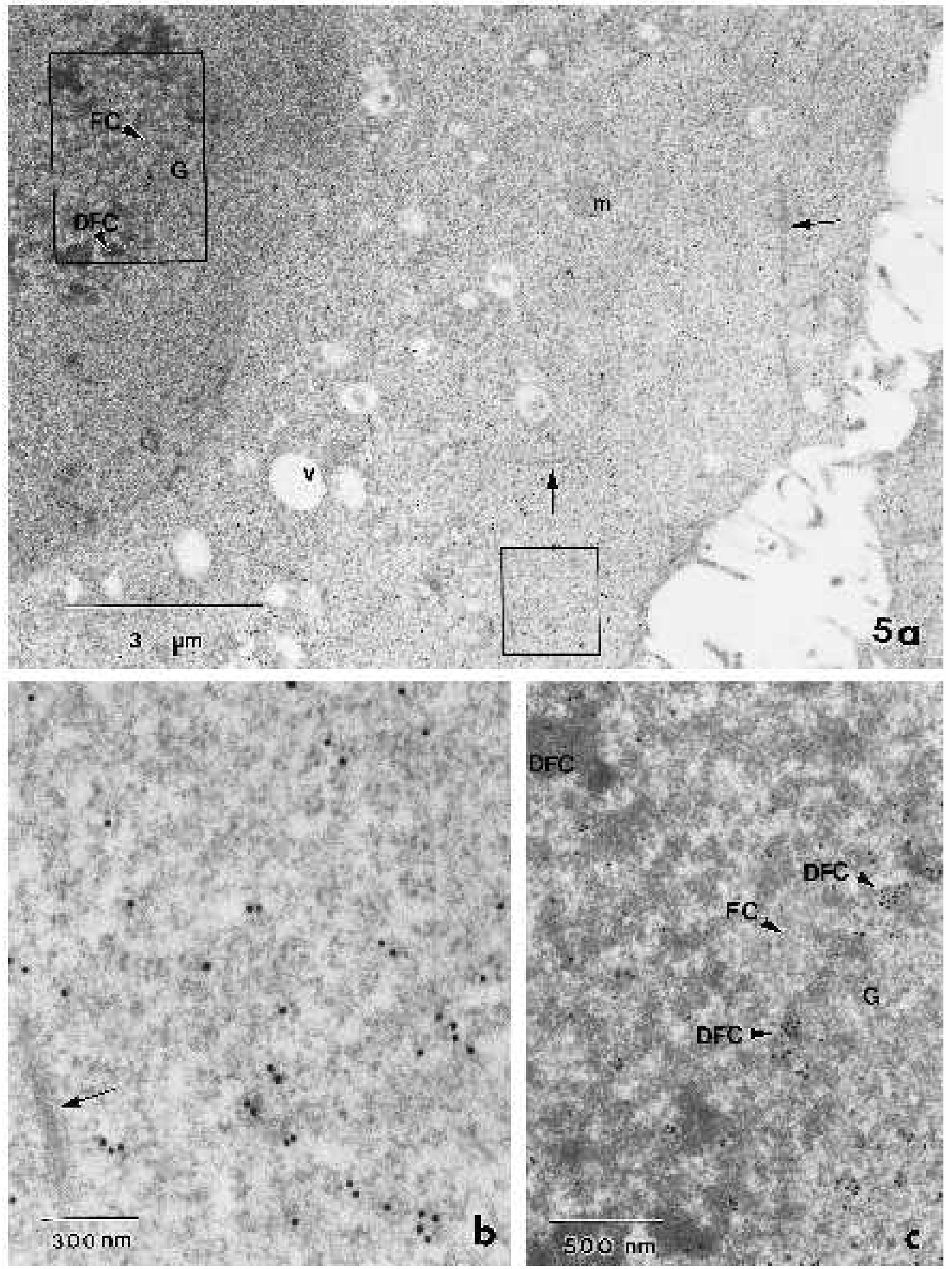

Fig. 5. Ultrastructural localization of DAI in uninfected HeLa cells using immunoelectron microscopy. DAI is present in ribosome enriched areas of the cytoplasm $(a, b)$, where cytoskeletal elements are observed (arrows) but are not immunolabeled. DAI is observed to a lesser extent in the nucleoplasm and the fibrillar portion of the nucleolus $(\mathrm{a}, \mathrm{c})$. Higher magnification of the cytoplasm (small square area in (a)) is shown in (b). Higher magnification of the nucleolus (large rectangular area in (a)) is shown in (c). m, mitochondrion; v, vacuole; FC, fibrillar center; DFC, dense fibrillar component; G, granular component. 
(Fig. 3a-f), but was excluded from the chromosomes. By late telophase and early $\mathrm{G}_{1}$ phase, DAI appeared in the newly forming nucleoli in every daughter cell (Fig. 3f, arrows). The distribution of DAI during interphase and mitosis parallels the distribution of rRNA as visualized by in situ hybridization (Jiménez-García et al., unpublished). Because of the nucleolar localization and its behavior during mitosis, we studied the distribution of DAI in actinomycin D (ActD)-treated cells (Fig. 4). ActD inhibits transcription by RNA polymerase I producing well defined morphological changes in the nucleolus (Ochs et al., 1985a). Upon ActD treatment, the three different components of the nucleolus spatially segregate in such a way that they are easily distinguishable from each other when observed using different staining techniques. This pattern is characterized by the presence of a large nucleolar body that is composed of the granular portion, and small buds that are constituted by the fibrillar portion, i.e. the dense fibrillar component and the fibrillar centers. When HeLa cells were treated in this manner, and then double labeled with anti-DAI and anti-fibrillarin antibodies, DAI and fibrillarin (which is a marker for the dense fibrillar component of the nucleolus; Ochs et al., 1985a), were segregated and colocalized to the fibrillar portion of the nucleolus (Fig. 4a,b).

The distribution of DAI in the cell was determined at high resolution by conducting immunoelectron microscopy on HeLa cell sections with monoclonal antibodies to DAI (Fig. 5). Label was observed in the ribosome-enriched areas of the cytoplasm, where cytoskeletal elements (arrows) were also visible but were not immunolabeled (Fig. 5a,b). Vacuoles and other organelles such as mitochondria, were unlabeled. The nucleoplasm was diffusely labeled (Fig. 5a). In the nucleolus, label was observed mainly in the dense fibrillar component although little label was visualized in the granular compartment and the fibrillar centers (Fig. $5 \mathrm{a}, \mathrm{c})$. To examine the distribution of DAI in Ad2-infected cells, infected HeLa cells were immunolabeled with monoclonal antibodies to DAI after hybridization to a total Ad2 probe to identify the infected cells and to determine the stage of infection that they had reached. At early and late stages after infection (visualized as cells with label as fine dots or abundant inclusions in the nucleus, respectively), DAI was observed both in the cytoplasm and in the nucleolus (Fig. 6a, arrows). Some diffuse label was also present in the nucleoplasm. Cytoplasmic viral RNA and DAI (Fig. 6b) were both diffusely distributed late in infection (heavily stained cell in Fig. 6b).

\section{VA RNA, is present in the cytoplasm and nucleus of Ad2-infected HeLa cells late in infection}

VA RNA I is produced abundantly during the late phase of adenovirus infection (Soderlund et al., 1976). We performed in situ hybridization in HeLa cells infected with Ad 2 for 24 hours to determine the cellular distribution of this RNA (Fig. 7). Hybridization signal was intense and diffusely distributed in the cytoplasm of infected cells (Fig. 7a). In the nucleus, VA RNAI was found in the form of small very intense bright round bodies, which were abundant and distributed throughout the nucleoplasm (Fig. 7a, arrowheads). In addition, VA RNA I was also detected in more elaborate ring-shaped viral inclusions. The nucleo-
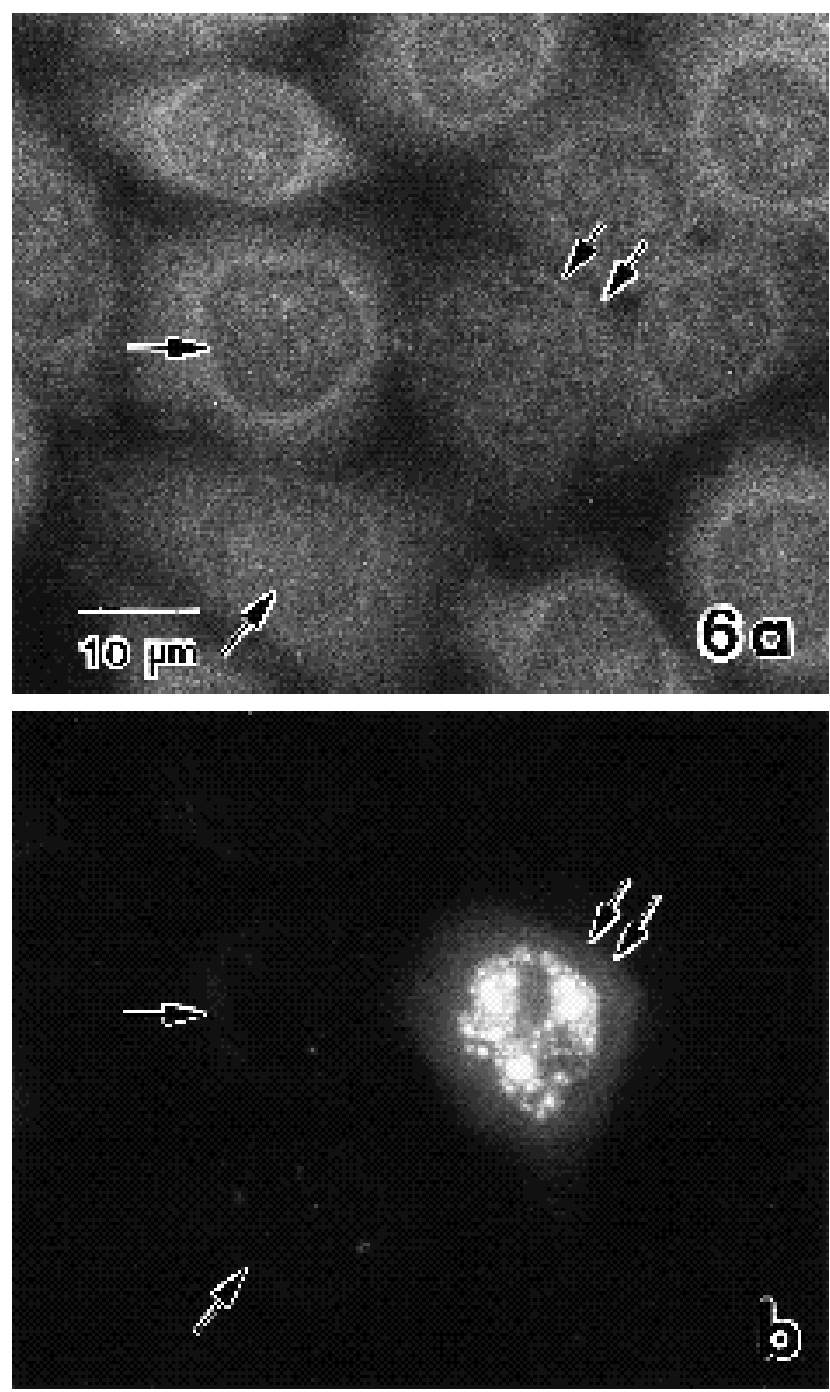

Fig. 6. Localization of DAI in Ad2-infected HeLa cells. In situ hybridization with a total genomic Ad2 DNA probe to identify infected cells (b), followed with anti-DAI (a) in the same cells shows the cytoplasmic distribution of DAI. In addition, the nucleolus and nucleoplasm are labeled for DAI. Cells in an early stage of infection are indicated by an arrow $(a, b)$. Double arrows show a cell late in infection.

lus, on the other hand, was unlabeled. To confirm that the signal observed in the nucleus and cytoplasm was specific for RNA and not for single-stranded viral DNA that is produced during Ad2 DNA replication (Lechner and Kelly, 1977), we performed nuclease digestions prior to the hybridization protocol. Cells incubated in $100 \mu \mathrm{g} / \mathrm{ml}$ of DNase I for 2 hours at room temperature still exhibited hybridization signal in the cytoplasm and the small rounded bodies in the nuclei (Fig. 7c). However, RNase A treatment prior to hybridization eliminated the hybridization signal in the cytoplasm and in the round nuclear inclusions (Fig. 7d). These data show that VA RNA I is contained within the small round inclusions. Control in situ hybridizations conducted without probe gave no signal (data not shown). To determine the pattern of expression 

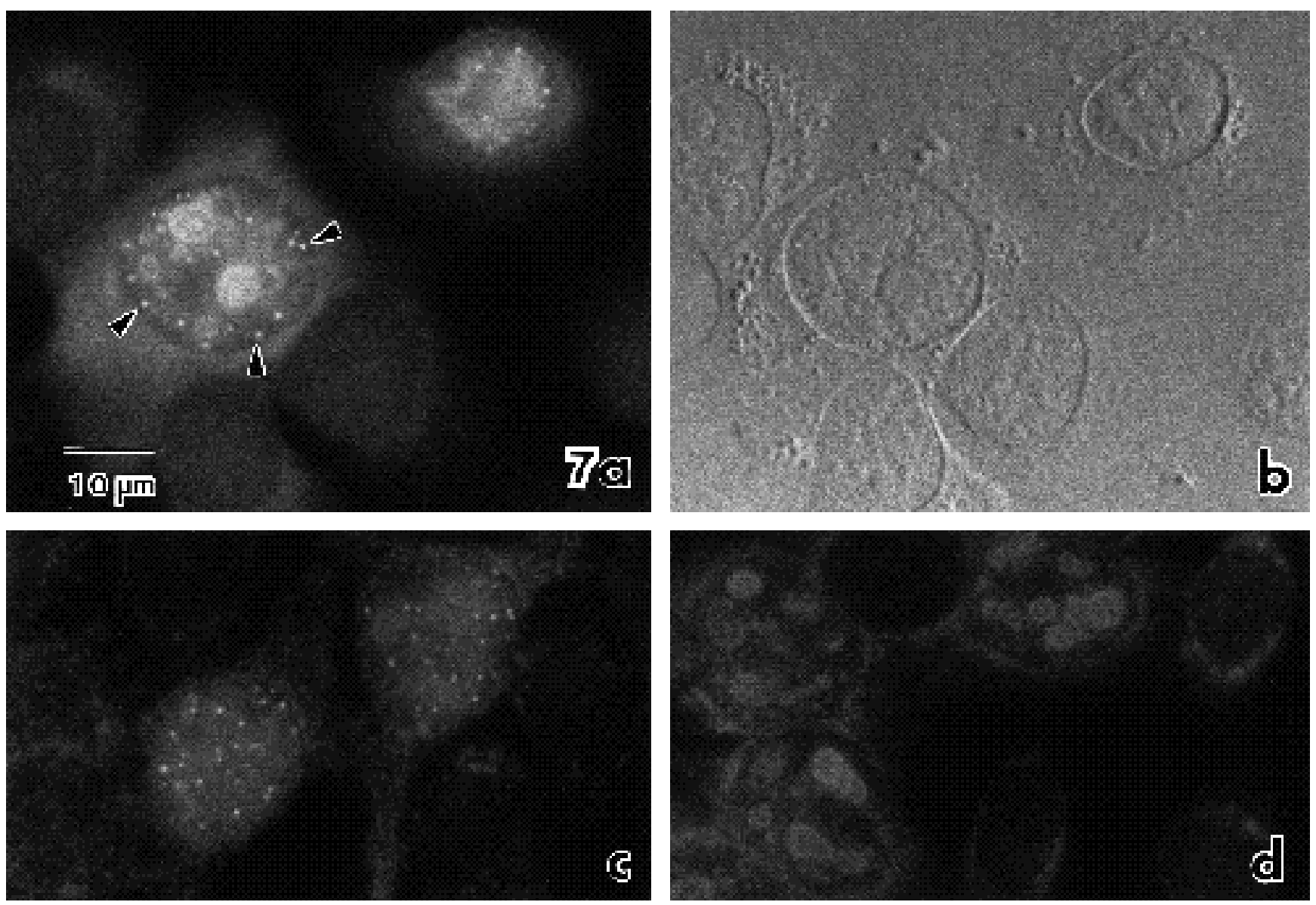

Fig. 7. Localization of VA RNAI in HeLa cells infected with Ad2 for 24 hours, using in situ hybridization. (a) VA RNAI appears to be localized in abundant small round dots in the nucleus (arrowheads) as well as being diffusely distributed in the cytoplasm.

(b) Corresponding differential interference contrast image. The hybridization signal (dots) are still observed after DNase I pre-treatment (c) but are not observed after RNase A pre-treatment (d).

of VA RNAI during the course of infection we performed in situ hybridization at 7, 10, 14, 18 and 24 hpi. For comparison, we also used an $\mathrm{Ad} 2$ genomic probe to localize total Ad2 RNA (Fig. 8). Total viral RNA was widely distributed and gave a very intense signal at 10-14 hpi (Fig. 8a) and 18-24 hpi (Fig. 8b). VA RNA I was first detected by 10-14 hpi as fine dots in the nucleoplasm and diffusely distributed in the cytoplasm of infected cells (Fig. 8c). By 18-24 hpi these fine and rounded bodies increased in size and number while the label in the cytoplasm also became more intense (Fig. 8d). No signal was observed before 10 hpi either in the nucleus or in the cytoplasm (data not shown).

To determine the three-dimensional distribution of the viral inclusions enriched in VA RNA in the infected nuclei, we reconstructed images of infected cells after in situ hybridization using a confocal laser scanning microscope. Fig. 9 shows a stereopair (where different planes of focus are displayed in the same picture) revealing the abundance of these bodies and their distribution at the different depths of the nuclei. The cytoplasm is observed to be homogeneously labeled.

We next wanted to determine whether the pattern of expression for VA RNA I reflects the intrinsic distribution characteristics of this molecule, or whether it is influenced by events occurring during viral infection. To this end, uninfected HeLa cells were transfected with the DNA encoding VA RNA I and were hybridized in situ after 24, 48 and 60 hours (Fig. 10). Cells transfected with the plasmid pUC119 containing no VA insert were not labeled (Fig. 10a). By 24 hours after transfection with a plasmid containing the VA RNA gene, VA RNAI started to appear as fine dots in the nucleoplasm (Fig. 10b). By 48 hours after transfection, VA RNA I was present as bigger dots in the nucleus and as a faint cytoplasmic distribution (Fig. 10c). By 60 hours post-transfection, the cytoplasm was even more heavily labeled than at 48 hours, and the nuclei were filled with bigger and more abundant round bodies, that were not present in the nucleolus (Fig. 10d). Therefore, the pattern of expression of VA RNA In transfected and Ad2 infected cells was similar.

\section{DISCUSSION}

We document here the localization of DAI in the cytoplasm and nucleolus of both uninfected and Ad2-infected HeLa cells; this pattern of distribution remained unchanged after 

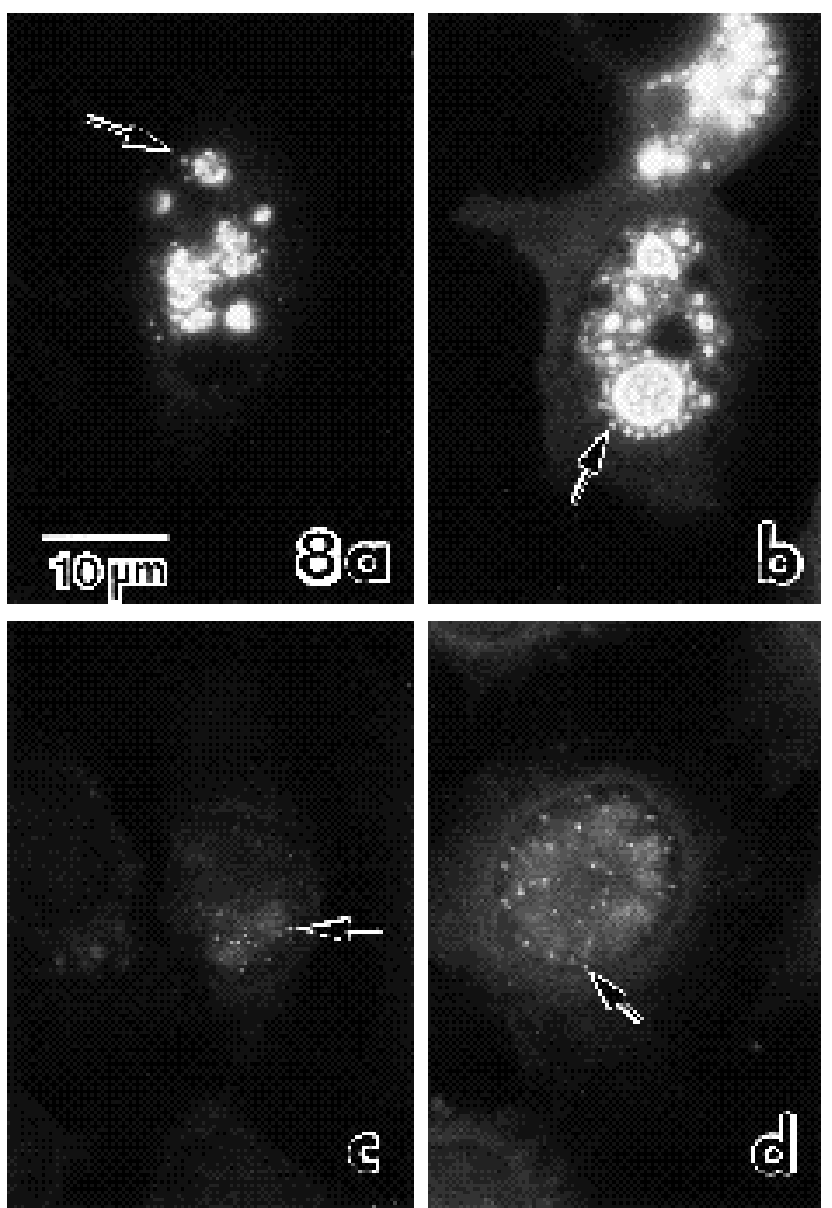

Fig. 8. Localization of VA RNAI at different time points after Ad2 infection by in situ hybridization. The first detectable VA RNAI signal appeared at about $10 \mathrm{hpi}$ (c) as very fine dots in the nucleoplasm, in association with the growing viral inclusions that contain ssDNA and RNA (a). Some diffuse cytoplasmic signal was also observed. By 24 hpi VA RNA I was present as larger dots in the nucleus and diffusely in the cytoplasm (d). Total Ad2 RNA at $10 \mathrm{hpi} \mathrm{(a)} \mathrm{or} 24 \mathrm{hpi} \mathrm{(b)} \mathrm{is} \mathrm{shown} \mathrm{for} \mathrm{comparison.}$

treatment of uninfected cells with $\alpha$-IFN, although IFN treatment elevates the amount of DAI protein in the cell by a factor of 5 to 10 (Hovanessian, 1989). Considering the role DAI has in the initiation of translation it was antici- pated that this protein would be present in the cytoplasm. It has been shown previously that many of the factors implicated in protein synthesis are compartmentalized in the cytoplasm. Active polysomes are associated with the cytoskeleton (Lenk et al., 1977) and translational initiation factors are associated with ribosomes and the cytoskeleton (Howe and Hershey, 1984). Our results confirm that at least one site of action for DAI is in the cytoplasm. The presence of DAI in the nucleolus and to a lesser extent in the nucleoplasm was unexpected. Interestingly, it was reported recently that eIF-4E is also partially located in the nucleus (Lejbkowicz et al., 1992) suggesting that many of the proteins participating in translation may also have roles in nuclear function. One may speculate as to the possible role of DAI in the nucleus. Since the nucleolus is known to be the site of pre-rRNA synthesis and ribosome assembly (Scheer and Benavente, 1990), the nucleolar localization of DAI may indicate that it has a role in the early stages of ribosome biogenesis. The nucleoplasmic staining may represent DAI migrating from the nucleolus to the cytoplasm. Alternatively, the nucleoplasmic presence of DAI in uninfected cells may be correlated with its ability to phosphorylate histones (Hovanessian, 1989) or other nuclear proteins (Ghosh and Baltimore, 1990).

Many nucleolar proteins are known to be present around the mitotic chromosomes and organized as prenucleolar bodies (PNB) that fuse to the nucleolar organizer (NOR), contributing to the newly formed interphase nucleolus at telophase (De la Torre and Giménez-Martín, 1982; Ochs et al., 1985b; Jiménez-García et al., 1989). During mitosis DAI was not found in PNB at telophase. DAI was first detected after mitosis during early $\mathrm{G}_{1}$. At this stage, the nucleoli are already active in transcription (De la Torre and Giménez-Martín, 1982), suggesting an association with the early phases of ribosome biogenesis. Since DAI has a strong cytoplasmic localization in addition to its nucleolar distribution, we considered the possibility that DAI may be associated with ribosomal subunits. Therefore, we treated cells with actinomycin D which inhibits ribosomal RNA synthesis and results in a segregation of nucleolar components. The behavior of nucleolar DAI upon actinomycin D treatment was the same as that of the nucleolar protein fibrillarin. It is known that fibrillarin is present in PNBs and it is the major nucleolar protein found in the dense fibrillar component of the nucleolus (Ochs et al., 1985a). Interest-
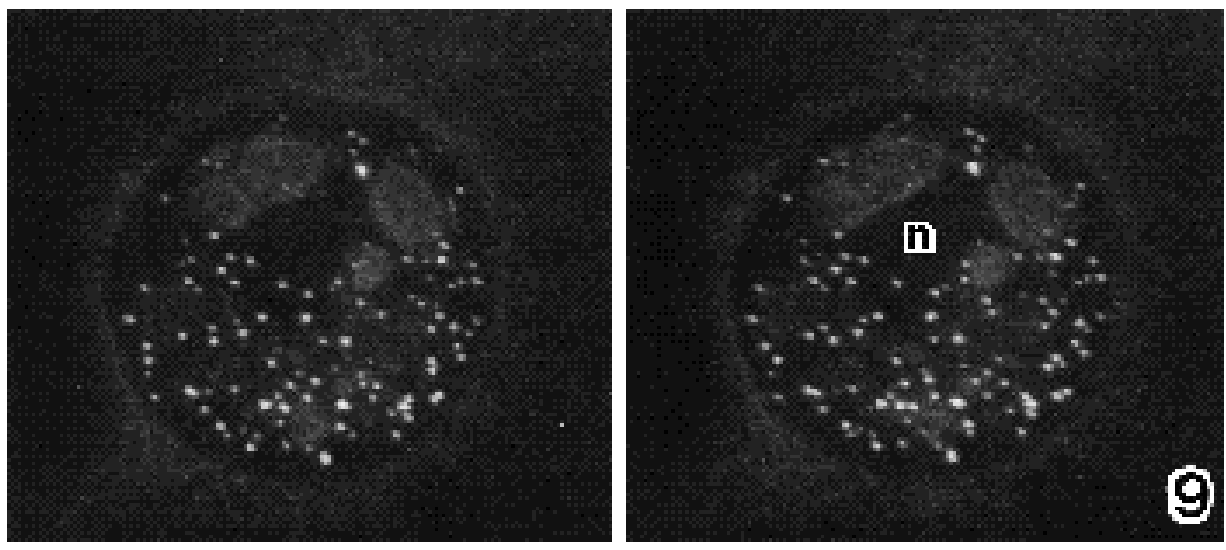

Fig. 9. Stereo images of VA RNAI localization in Ad2 infected HeLa cells. The three-dimensional organization of VA RNA is visualized as small, round bodies in the nucleoplasm. The cytoplasmic portion of VA RNA is diffusely distributed. 

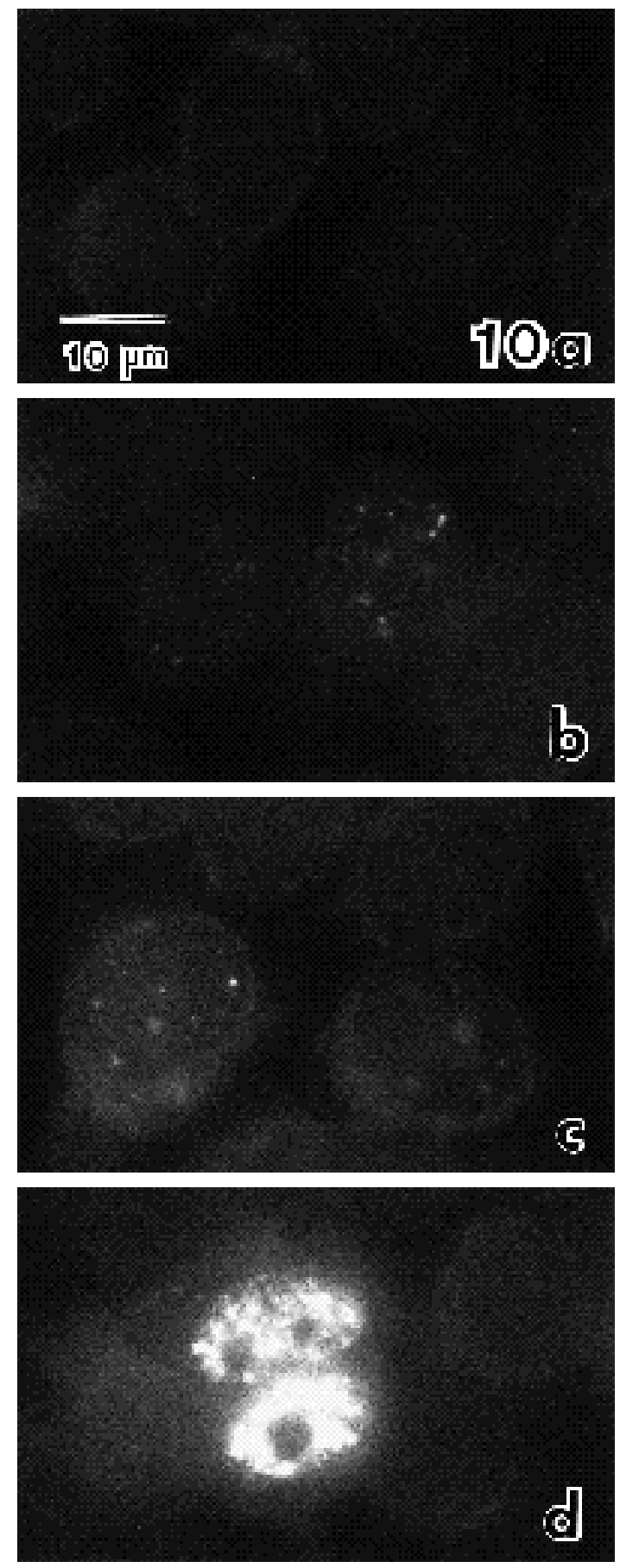

Fig. 10. Localization of VA RNA I in transfected HeLa cells. The morphological pattern of expression for VA RNAI is similar to that of Ad2 infected HeLa cells. No signal is observed in cells transfected with plasmid pUC119 (a). By 24 hours (b) after transfection with pUCVA, VA RNAI appears as fine dots in the nucleoplasm. At 48 hours (c) the label is more abundant in the nucleus and some VA RNA is observed in the cytoplasm. By 60 hours after transfection (d) the nucleus is filled with VA RNAI excluding the nucleoli. The cytoplasm at this time is heavily labeled. ingly, fibrillarin is present in the nucleolar U3 snRNP (Lischwe et al., 1985; Ochs et al., 1985a; Reimer et al., 1987; Reddy and Busch, 1988). U3 snRNA has been implicated in the first steps of pre-rRNA processing (Kass et al., 1990; Tollervey et al., 1991). Therefore, the localization of DAI with fibrillarin may be of functional significance. Moreover, by immunoelectron microscopy, we found DAI to be present in the dense fibrillar component of the nucleolus, although a small amount of label was also found in the fibrillar centers and in the granular component of the nucleolus. A possible role of DAI in the first steps of ribosome biogenesis, indicated by its presence in the dense fibrillar component of the nucleolus, remains to be demonstrated.

The presence of VA RNAI in the cytoplasm of Ad2infected HeLa cells was observed after about 10 hpi and became increasingly evident at later times. Our inability to detect transcripts before $10 \mathrm{hpi}$ is presumably due to the low abundance of VA RNAI during the early phase of infection (Söderlund et al., 1976) and the insensitivity of the in situ hybridization technique used. Unlike DAI, the observation of this RNA in the nucleus was not unexpected since adenovirus transcripts are produced in the nucleus of the host cell during the lytic cycle (Akusjärvi et al., 1986). Surprisingly, highly organized structures containing VA RNAI appear by 10-14 hpi as spherical bodies in the nucleoplasm, becoming larger and more numerous as the infectious cycle progresses. These bodies represent a subset of the total adenovirus RNA (Jiménez-García and Spector, 1993) and suggest a mechanism of accumulation and migration for VA RNA I in the nucleus. Because VA RNAI is transcribed by RNA polymerase III (Price and Penman, 1972) while the rest of the viral genome is transcribed by RNA polymerase II (see Akusjärvi et al., 1986), the presence of these bodies containing VA RNAI may be related to a different site of synthesis and/or transport pathway for transcripts produced by RNA polymerase III. Supporting this contention is the finding that transfected cells displayed the same morphological pattern of localization of this RNA as infected cells, namely the progressive appearance of dots, suggesting that the transcription and/or transport to the cytoplasm of RNA polymerase III transcripts may occur via highly defined nuclear structures. These viral inclusions containing VA RNAI may represent the viral RNA-rich compact rings observed by ultrastructural in situ hybridization in Ad5-infected cells late in infection (PuvionDutilleul et al., 1992). However, it is unlikely that these structures are regions of RNA processing since the VA $\mathrm{RNA}_{\mathrm{I}}$ is not post-transcriptionally processed.

VA RNAI was expressed in two steps during the late phase of infection. First, nuclear RNA accumulated as small round bodies that became numerous. Subsequently, the RNA accumulated diffusely in the cytoplasm. Indeed, VA

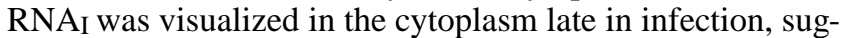
gesting a final destination corresponding to its function in the cytoplasm during protein synthesis. These experiments may suggest a specific signal for VA RNAI to be present in the cytoplasm. That signal may have something to do with the molecular structure of the RNA or with the presence of latent DAI in the cytoplasm.

DAI (Zilberstein et al., 1976) and VA RNAI (Schneider et al., 1985) have been found in association with ribosomes. 
It has been proposed that VA RNAI and Ad2 mRNAs are associated in infected cells in a manner that results in a functional compartmentalization (O'Malley et al., 1989). The presence of the VA RNA I protects the translation of Ad2 mRNAs from DAI activation by virally generated dsRNA, while cellular mRNAs, which do not bind VA RNAI are not protected and therefore not translated. The colocalization of DAI with VA RNA I in the cytoplasm may represent such a compartmentalization. Furthermore, the presence of both DAI and VA RNA in the nucleus, though predominantly not colocalized, suggests the possibility that the association between Ad2 mRNAs, VA RNA I and DAI may originate in the nucleus prior to export into the cytoplasm. Future experiments will examine the organization of other translational elements in the cytoplasm of $\mathrm{Ad} 2$ infected cells.

In summary, we have shown that DAI is present in the cytoplasm, in the nucleoplasm, and in the nucleolus of uninfected and Ad2-infected HeLa cells. In the nucleolus, DAI was found predominantly, although not exclusively, in the dense fibrillar component. On the other hand, VA RNAI was also present in the cytoplasm and in the nucleus of Ad2-infected HeLa cells. In the nucleus, VA RNA I was observed to be present in abundant, highly organized, small, round structures distributed in the nucleoplasm, but was excluded from the nucleolus. Both DAI and VA RNAI were diffusely localized in the cytoplasm.

We thank A. Hovanessian (Institut Pasteur, Paris, France) for providing the monoclonal antibody to DAI, R. L. Ochs (Scripps Research Institute, LaJolla, California) for human autoantibody to fibrillarin, Paul Trotta (Schering Corp. Bloomfield, New Jersey) for Interferon, and Lisa Manche (CSHL) for helping us with the transfection experiments. This work was supported by grants from the American Cancer Society (NP-619-A) and the National Institutes of Health (GM42694 and 5P30 CA45508-03) to D.L.S. and by program project grant CA 13106 from the National Cancer Institute to M.B.M. L.F.J.-G. is a postdoctoral fellow from the Department of Biology of the Faculty of Sciences, funded by the National Autonomous University of Mexico (DGAPA, UNAM).

\section{REFERENCES}

Akusjärvi, G., Mathews, M. B., Anderson, P., Vennström, B. and Pettersson, U. (1980). Structure of genes for virus-associated RNA $\mathrm{I}$ and RNA $_{\text {II }}$ of adenovirus type 2. Proc. Nat. Acad. Sci. USA 77, 2424-2428.

Akusjärvi, G., Pettersson, U. and Roberts, R. (1986). Structure and function of the adenovirus-2 genome. In Adenovirus DNA (ed. W. Doerfler), pp. 53-95. Martinus Nijhoff Publishing, Boston.

Beltz, G. A. and Flint, S. J. (1979). Inhibition of HeLa cell protein synthesis during adenovirus infection. Restriction of cellular messenger RNA sequences to the nucleus. J. Mol. Biol. 131, 353-373.

Brasch, K. and Ochs, R. L. (1992). Nuclear bodies (NBs): a newly 'rediscovered' organelle. Exp. Cell Res. 202, 211-223.

Chebath, J., Benech, P., Hovanessian, A., Galabru, J. and Revel, M. (1987). Four different forms of interferon-induced 2', 5'-oligo (A) synthetase identified by immunoblotting in human cells. J. Biol. Chem. 262, 3852-3857.

Choubey, D. and Lengyel, P. (1992). Interferon action: nucleolar and nucleoplasmic localization of the interferon-inducible $72-\mathrm{kD}$ protein that is encoded by the Ifi204 gene from the gene 200 cluster. J. Cell Biol. 116, 1333-1341.

Darnell, J. E. Jr (1982). Variety in the level of gene control in eukaryotic cells. Nature 297, 365-371.

De la Torre, C. and Giménez-Martín, G. (1982). The nucleolar cycle. In
The Nucleolus (ed. E. G. Jordan and C. A. Cullis), pp. 153-177. Cambridge University Press, Cambridge, UK.

Flint, S. J. (1986). Regulation of adenovirus mRNA formation. Advan. Virus Res. 31, 169-228.

Furtado, M. R., Subramanian, S., Bhat, R. A., Fowlkes, D. H., Safer, B. and Thimmappaya, B. (1989). Functional dissection of adenovirus VA I RNA. J. Virol. 63, 3423-3434.

Galabru, J. and Hovanessian, A. G. (1987). Autophosphorylation of the protein kinase dependent on double-stranded RNA. J. Biol. Chem. 262, 15538-15544.

Galabru, J., Katze, M. G., Robert, N. and Hovanessian, A. G. (1989). The binding of double-stranded RNA and adenovirus VA I RNA to the interferon-induced protein kinase. Eur. J. Biochem. 178, 581-589.

Ghadge, G. D., Swaminathan, S., Katze, M. G. and Thimmappaya, B. (1991). Binding of the adenovirus VA I RNA to the interferon-induced 68 kDa protein kinase correlates with function. Proc. Nat. Acad. Sci. USA 88 , 7140-7144.

Ghosh, S. and Baltimore D. (1990). Activation in vitro of NF- $\mathrm{KB}$ by phosphorylation of its inhibitor IкB. Nature 344, 678-682.

Green, S. R. and Mathews, M. B. (1992). Two RNA binding motifs in the double-stranded RNA activated protein kinase, DAI. Genes Dev. 6, 24782490.

Hovanessian, A. G. (1989). The double stranded RNA-activated protein kinase induced by interferon: dsRNA-PK. J. Interferon Res. 9, 641-647.

Howe, J. G. and Hershey, J. W. B. (1984). Translational initiation factor and ribosome association with the cytoskeletal framework fraction from HeLa cells. Cell 37, 85-93.

Huang, S. and Spector, D. L. (1991). Nascent pre-mRNA transcripts are associated with nuclear regions enriched in splicing factors. Genes Dev. $\mathbf{5}$, 2288-2302.

Jiménez-García, L. F., Rothblum, L. I., Busch, H. and Ochs, R. L. (1989). Nucleologenesis: use of non-isotopic in situ hybridization and immunocytochemistry to compare the localization of rDNA and nucleolar proteins during mitosis. Biol. Cell 65, 239-246.

Jiménez-García, L. F. and Spector, D. L. (1993). In vivo evidence that transcription and pre-mRNA splicing are coordinated by a recruiting mechanism. Cell 73, 47-59.

Kass, S., Tyc, K., Steitz, J. A. and Sollner-Webb, B. (1990). The U3 small nucleolar ribonucleoprotein functions in the first step of preribosomal RNA processing. Cell 60, 897-908.

Katze, M. G., DeCorato, D., Safer, B., Galabru, J. and Hovanessian, A. G. (1987). Adenovirus VA I RNA complexes with the $60,000 \mathrm{Mr}$ protein kinase to regulate its autophosphorylation and activity. EMBO J. 6, 689697.

Kostura, M. and Mathews, M. B. (1989). Purification and activation of the double-stranded RNA-dependent eIF-2 kinase DAI. Mol. Cell. Biol. 9, 1576-1586.

Laurent, A. G., Krust, B., Galabru, J., Svab, J. and Hovanessian, A. G. (1985). Monoclonal antibodies to an interferon-induced $\mathrm{Mr} 68,000$ protein and their use for the detection of double-stranded RNA-dependent protein kinase in human cells. Proc. Nat. Acad. Sci. USA 82, 43414345

Lechner, R. L. and Kelly, T. J. Jr (1977). The structure of replicating adenovirus type 2 DNA molecules. Cell 12, 1007-1020.

Lejbkowicz, F., Goye, C., Darveau, A., Neron, S., Lamieux, R. and Sonenberg, N. (1992). A fraction of the mRNA 5' cap-binding protein, eukaryotic initiation factor 4E, localizes to the nucleus. Proc. Nat. Acad. Sci. USA 89, 9612-9616.

Lenk, R., Ransom, L., Kaufmann, Y. and Penman, S. (1977). A cytoskeletal structure associated with polyribosomes obtained from HeLa cells. Cell 10, 67-78.

Lischwe, M. A., Ochs, R. L., Reddy, R., Yeoman, L. C., Tan, E. M., Reichlin, M. and Busch, H. (1985). Purification of a nucleolar scleroderma antigen (Mr: 34,000; pI: 8.5) rich in $\mathrm{NG}_{-} \mathrm{N}_{-}$ dimethylarginine. J. Biol. Chem. 260, 14304-14310.

Maran, A. and Mathews, M. B. (1988). Characterization of the doublestranded RNA implicated in the inhibition of protein synthesis in cells infected with a mutant adenovirus defective for VA RNA . Virology $\mathbf{1 6 4}$, 106-113.

Mathews, M. B. (1975). Genes for VA-RNA in adenovirus 2. Cell 6, 223229.

Mathews, M. B. (1990). Control of translation in Adenovirus-infected cells. Enzyme 44, 250-264.

Mathews, M. B., Gunnery, S., Manche, L., Mellits, K. H. and Pe'ery, T. 
(1990). Control of protein synthesis by protein regulators. In Posttranscriptional Control of Gene Expression (ed. J. E. G. McCarthy and M. F. Tuite), pp. 377-388. Springer Verlag, Berlin.

Mathews, M. B. and Pettersson, U. (1978). The low molecular weight RNAs of adenovirus 2-infected cells. J. Mol. Biol. 119, 293-328.

Mathews, M. B. and Shenk, T. (1991). Adenovirus virus-associated RNA and translational control. J. Virol. 65, 5657-5662.

McGrogan, M. and Raskas, H. J. (1977). Species identification and genome mapping of cytoplasmic adenovirus type 2 RNAs synthesized late in infection. J. Virol. 23, 240-249.

Mellits, K. H., Kostura, M. and Mathews, M. B. (1990a). Interaction of adenovirus VA RNA with the protein kinase DAI: non-equivalence of binding and function. Cell 61, 843-852.

Mellits, K. H. and Mathews, M. B. (1988). Effects of mutations in stem and loop regions on the structure and function of adenovirus VA RNAI. EMBO J. 7, 2849-2859.

Mellits, K. H., Pe'ery, T., Manche, L., Robertson, H. D. and Mathews, M. B. (1990b). Removal of double-stranded contaminants from RNA transcripts: synthesis of adenovirus VA RNAI from a T7 vector. Nucl. Acids Res. 18, 5401-5406.

Nevins, J. R. and Darnell, J. E. Jr (1978). Steps in the processing of Ad2 mRNA: poly(A)+ nuclear sequences are conserved and poly(A) addition precedes splicing. Cell 15, 1477-1493.

Ochs, R. L., Lischwe, M. A., Spohn, W. H., Busch, H. (1985a). Fibrillarin: a new protein of the nucleolus identified by autoimmune sera. Biol. Cell 54, $123-134$.

Ochs, R. L., Lischwe, M. A., Shen, E., Carroll, R. E. and Busch, H. (1985b). Nucleologenesis: composition and fate of prenucleolar bodies. Chromosoma 92, 330-336.

O'Malley, R. P., Duncan, R. F., Hershey, J. W. and Mathews, M. B. (1989). Modification of protein synthesis initiation factors and the shutoff of host protein synthesis in adenovirus-infected cells. Virology 168 , 112-118.

Pavlovic, J. and Staehli, P. (1991). The antiviral potentials of Mx proteins. J. Interferon Res. 11, 215-219.

Pe'ery, T., Mellits, K. and Mathews, M. B. (1993). Mutational analysis of the central domain of adenovirus-associated RNA mandates a revision of the proposed secondary structure. J. Virol. 67, 3534-3543.

Pestka, S., Langer, J. A., Zoon, K. C. and Samuel, C. E. (1987). Interferons and their actions. Annu. Rev. Biochem. 56, 727-777.

Pettersson, U. (1984). Structural and nonstructural adenovirus proteins. In The Adenoviruses (ed. H. S. Ginsberg), pp. 205-270. Plenum Press, New York.

Philipson, L. (1979). Adenovirus proteins and their messenger RNAs. Adv Virus Res. 25, 357-405.

Price and Penman (1972). A distinct RNA polymerase activity, synthesizing 5.5S, 5S and 4S RNA in nuclei from adenovirus 2-infected HeLa cells. J. Mol. Biol. 70, 435-450.

Puvion-Dutilleul, F., Rousseu, R. and Puvion, E. (1992). Distribution of viral RNA molecules during the adenovirus 5 infectious cycle in HeLa cells. J. Struct. Biol. 108, 209-220.

Reddy, R. and Busch, H. (1988). Small nuclear RNAs: RNA sequences, structure and modifications. In Structure and Function of Major and Minor Small Nuclear Ribonucleoprotein Particles (ed. M. L. Birnstiel), pp. 1-37. Springer-Verlag, Berlin.

Reich, P. R., Forget, B. G., Weissman, S. M. and Rose, J. A. (1966). RNA of low molecular weight in KB cells infected with adenovirus type 2. $J$. Mol. Biol. 17, 428-439.

Reichel, P. A., Merrick, W. C., Siekierka, J. and Mathews, M. B. (1985). Regulation of a protein synthesis initiation factor by adenovirus virusassociated RNA. Nature 313, 196-200.

Reimer, G., Pollard, K. M., Penning, C. A., Ochs, R. L., Lischwe, M. A., Busch, H. and Tan, E. (1987). Monoclonal antibody from (New Zealand Black $\times$ New Zealand White) F1 mouse and some human scleroderma sera target an Mr 34,000 nucleolar protein of the U3 RNP particle. Arthritis Rheum. 30, 793-800.

Scheer, U. and Benavente, R. (1990). Functional and dynamic aspects of the mammalian nucleolus. BioEssays 12, 14-21.

Schneider, R. J., Safer, B., Munemitsu, S. M., Samuel, C. E. and Shenk, T. (1985). Adenovirus VAI RNA prevents phosphorylation of the eukaryotic initiation factor $2 \alpha$ subunit subsequent to infection. Proc. Nat. Acad. Sci. USA 82, 4321-4325.

Schneider, R. J., Weinberger, C. and Shenk, T. (1984). Adenovirus VAI RNA facilitates the initiation of translation in virus-infected cells. Cell 37, 291-298.

Sharp, P. A. (1984). Adenovirus trasncription. In The Adenoviruses (ed. H. S. Ginsberg), pp. 173-204. Plenum Press, New York.

Söderlund, H., Pettersson, U., Vennström, B., Philipson, L. and Mathews, M. B. (1976). A new species of virus-coded low molecular weight RNA from cells infected with Ad2. Cell 7, 585-593.

Spector, D. L., Lark, G. and Huang, S. (1992). Differences in snRNP localization between transformed and nontransformed cells. Mol. Biol. Cell 3, 555-569.

Spector, D. L. and Smith, H. C. (1986). Redistribution of U-snRNPs during mitosis. Exp. Cell Res. 163, 87-94.

Stewart, P. L., Burnett, R. M., Cyrklaff, M. and Fuller, S. D. (1991). Image reconstruction reveals the complex molecular organization of adenovirus. Cell 67, 145-154.

Svensson, C. and Akusjärvi, G. (1985). Adenovirus VA RNA I mediates the translational stimulation which is not restricted to the viral mRNAs. EMBO J. 4, 957-964.

Thimmappaya, B., Weinberger, C., Schneider, R. J. and Shenk, T. (1982). Adenovirus VAI RNA is required for efficient translation of viral mRNAs at late times after infection. Cell 31, 543-551.

Tollervey, D., Lehtonen, H., Carmo-Fonseca, M. and Hurt, E. C. (1991). The small nucleolar RNP protein NOP1 (fibrillarin) is required for prerRNA processing in yeast. EMBO J. 10, 573-583.

Tooze, J. (1982). The Molecular Biology of Tumor Viruses, Vol. 2. DNA Tumor Viruses, 2nd edn. Cold Spring Harbor Laboratory Press, New York.

Wigler, M., Pellicer, A., Silverstein, S. and Axel, R. (1978). Biochemical transfer of single-copy eukaryotic genes using total cellular DNA as donor. Cell 14, 725-731.

Zhang, Y. and Schneider, R. J. (1993). Translational regulation in adenovirus infected cells. Semin. Virol. (in press).

Ziff, E. B. (1980). Transcription and RNA processing by the DNA tumour viruses. Nature 287, 491-499.

Zilberstein, A., Federmann, P., Schulman, L. and Revel, M. (1976). Specific phosphorylation in vitro of a protein associated with ribosomes of interferon treated mouse cells. FEBS Lett. 68, 119-124.

(Received 6 April 1993 - Accepted 2 June 1993) 